\title{
Caracterização molecular do sistema de grupo sangüíneo Dombrock em uma população brasileira
}

\section{Molecular characterization of the Dombrock blood group system in a Brazilian population}

Wilson Baleotti Jr

Orientadora

Lilian M. de Castilho

\section{Resumo}

O sistema de grupo sangüíneo Dombrock é constituído por um par de antígenos antitéticos, Do e Do ${ }^{\mathrm{b}}$ e três antígenos de alta freqüência populacional, Gregory $\left(\mathrm{Gy}^{\mathrm{a}}\right)$, Holley (Hy) e Joseph $\left(\mathrm{Jo}^{\mathrm{a}}\right)$. O gene $D O$, que codifica os antígenos do sistema Dombrock, foi recentemente clonado e suas bases moleculares foram elucidadas.

Os antígenos $\mathrm{Do}^{\mathrm{a}} \mathrm{e} \mathrm{Do}^{\mathrm{b}}$, são controlados pelos alelos DOA e $D O B$, que estão associados à troca de três nucleotídeos no exon 2 do gene $D O: 378 \mathrm{C} / \mathrm{T}, 624 \mathrm{~T} / \mathrm{C}$ e $793 \mathrm{~A} / \mathrm{G}$, respectivamente. O fenótipo Jo(a-) está associado com a substituição 350C/T, que caracteriza o alelo $J O$. O fenótipo Hy-negativo está associado à presença de um dos alelos: HY1 ou HY2. O alelo HY2 é caracterizado pela substituição 323G/T. Uma substituição adicional 898C/G, no exon 3, caracteriza o gene $H Y 1$. Recentemente, dois novos alelos do gene $D O$ foram descritos: $\mathrm{DOB}-\mathrm{SH}$ (378C, 624C, 793G) e DOA-HA (378T, 624T, 793A).

Considerando que as bases moleculares dos antígenos Dombrock foram elucidadas; que novos alelos têm sido descritos; a miscigenação da população brasileira e que, até o momento, nenhum estudo foi realizado sobre a freqüência dos genes Dombrock na nossa população, nós analisamos 450 amostras de DNA, através das técnicas de PCR-RFLP e Microarrays ${ }^{\circledR}$ - HEA Beadchip, com a finalidade de determinar a freqüência dos alelos $D O(D O A, D O B$, HY1, HY2, JO).

Dois novos alelos foram identificados baseados em novas combinações de SNPs: alelo DOB-WL (793G, 898G, 323G) e alelo DOA-SH (378C, 624C, 793A). Nossos dados demonstram uma grande complexidade e heterogeneidade dos alelos Dombrock na população brasileira e confirmam a necessidade do estudo molecular em diferentes populações.
Abstract

The molecular basis of the $\mathrm{Do}^{\mathrm{a}}$ and $\mathrm{Do}^{\mathrm{b}}$ polymorphisms are associated with three single-nucleotide polymorphisms (SNPs) on exon 2 of the $D O$ gene: $378 \mathrm{C}>\mathrm{T}, 624 \mathrm{~T}>\mathrm{C}$ and $793 \mathrm{~A}>\mathrm{G}$, the $D O A$ and DOB alleles. The SNPs 350C $>\mathrm{T}$ ( $\mathrm{JO}$ allele) and 323G $>\mathrm{T}$ (HY allele) are associated with: Jo(a-) and Hy-negative phenotypes. Recently, two new DO alleles were identified using microarray technology, DOB-SH (378C, 624C, 793G) and DOA-HA (378T, 624T, 793A). Although the molecular background of the Dombrock system is well defined, no studies have been carried out in the Brazilian population.

We used PCR-RFLP based assays and a microarray assay to determine the frequency of the $D O$ alleles (DOA, DOB, HY1, HY2 and $J O$ ) in Brazilians. We tested the DNA of 288 individuals by PCR-RFLP to determine the 793A $>\mathrm{G}$ (DOA/DOB), 323G $>\mathrm{T}$ (HY), $350 \mathrm{C}>\mathrm{T}(\mathrm{JO})$ and $898 \mathrm{C}>\mathrm{G}(H Y 1 / H Y 2)$ SNPs. We also tested DNA from 162 blood donors using HEA Beadchip ${ }^{\mathrm{TM}}$ (BioArray Solutions, USA) to determine the $378 \mathrm{C}>\mathrm{T}, 624 \mathrm{~T}>\mathrm{C}, 793 \mathrm{~A}>\mathrm{G}(\mathrm{DOA} / \mathrm{DOB})$, 350C $>\mathrm{T}$ ( $\mathrm{JO}$ allele) and 323G $>\mathrm{T}(H Y)$ SNPs.

Two novel allelic combinations were found in our samples: the 793G SNP (DOB allele) associated with 898G and 323G (DOBWL) and the 378C, 624C, 793A and 323G (DOA-SH) SNPs. We also found the recently reported $D O B-S H$ and $D O A-H A$ alleles.

Our data demonstrate the high heterogeneity of $D O$ alleles in the Brazilian population and highlight the importance of testing a cohort of different populations to determine $D O$ allelic combinations and establish reliable genotyping to predict the $\mathrm{Do}^{\mathrm{a}} / \mathrm{Do}^{\mathrm{b}}$ antigen status.

Avaliação: A Revista Brasileira de Hematologia e Hemoterapia publica os resumos e abstracts de teses da área apresentados em entidades que tenham programas de pós-graduação reconhecidos pelo MEC/Capes e considera a obtenção do título suficiente para sua publicação na forma como se propõe a seção.

Recebido: 06/09/2006

Aceito: 26/09/2006

Tese de Doutorado apresentada à Pós-graduação da Faculdade de Ciências Médicas da Universidade Estadual de Campinas para obtenção do grau de Doutor em Clínica Médica na área de Ciências Básicas.

Correspondência: Wilson Baleotti Jr.

Faculdade de Medicina de Marília - Hemocentro

Rua Lourival Freire $n^{\circ} 240$

17.519-050 - Marília-SP - Brasil

E-mail: baleotti@famema.br 